\title{
Effect of insulin and glucose on adenosine metabolizing enzymes in human B lymphocytes
}

\author{
Katarzyna Kocbuch ${ }^{\boxplus}$, Monika Sakowicz-Burkiewicz ${ }^{1}$, Marzena Grdenㄹ, \\ Andrzej Szutowicz ${ }^{2}$ and Tadeusz Pawelczyk ${ }^{1}$ \\ ${ }^{1}$ Department of Molecular Medicine, ${ }^{2}$ Department of Laboratory Medicine, Medical University of Gdansk, \\ Gdańsk, Poland
}

Received: 24 April, 2009; revised: 15 July, 2009; accepted: 31 August, 2009

available on-line: 07 September, 2009

\begin{abstract}
In diabetes several aspects of immunity are altered, including the immunomodulatory action of adenosine. Our study was undertaken to investigate the effect of different glucose and insulin concentrations on activities of adenosine metabolizing enzymes in human B lymphocytes line SKW 6.4. The activity of adenosine deaminase in the cytosolic fraction was very low and was not affected by different glucose concentration, but in the membrane fraction of cells cultured with $25 \mathrm{mM}$ glucose it was decreased by about 35\% comparing to the activity in cells maintained in $5 \mathrm{mM}$ glucose, irrespective of insulin concentration. The activities of $5^{\prime}$-nucleotidase $\left(5^{\prime}\right.$-NT) and ecto-5'-NT in SKW 6.4 cells depended on insulin concentration, but not on glucose. Cells cultured with $10^{-8} \mathrm{M}$ insulin displayed an about $60 \%$ lower activity of cytosolic $5^{\prime}$-NT comparing to cells maintained at $10^{-11} \mathrm{M}$ insulin. The activity of ecto-5'-NT was decreased by about $70 \%$ in cells cultured with $10^{-8} \mathrm{M}$ insulin comparing to cells grown in $10^{-11} \mathrm{M}$ insulin. Neither insulin nor glucose had an effect on adenosine kinase (AK) activity in SKW 6.4 cells or in human $B$ cells isolated from peripheral blood. The extracellular level of adenosine and inosine during accelerated catabolism of cellular ATP depended on glucose, but not on insulin concentration. Concluding, our study demonstrates that glucose and insulin differentially affect the activities of adenosine metabolizing enzymes in human B lymphocytes, but changes in those activities do not correlate with the adenosine level in cell media during accelerated ATP catabolism, implying that nucleoside transport is the primary factor determining the extracellular level of adenosine.
\end{abstract}

Keywords: insulin, glucose, adenosine kinase, adenosine deaminase, 5'-nucleotidase, B lymphocytes

\section{INTRODUCTION}

Several cytokines, hormones and small signalling molecules regulate functioning of immunological cells. Adenosine is an endogenous nucleoside exerting potent immunomodulatory action. Under in vitro conditions adenosine has the ability to alter events such as lymphocyte activation, proliferation, cytokine production, and lymphocyte-mediated cytolysis (Hasko \& Cronstein, 2004; Hershfield, 2005; Gessi et al., 2007; Hasko et al., 2008). These adenosine actions result from ligation of cell surface adenosine receptors (ARs) and subsequent activation of downstream intracellular pathways. Individual
ARs show different affinities for adenosine (Fredholm et al., 2001); therefore, the cellular response to this nucleoside depends on its concentration. Relatively constant local concentrations of adenosine are maintained by its metabolism and transport. However, under stress conditions, such as enhanced oxygen supply or inflammation (Sperlagh et al., 2000; Martin et al., 2000), increased amounts of adenosine are formed, resulting in an elevation of its local concentration. Our previous work has documented an increased concentration of adenosine in several tissues of diabetic rats (Pawelczyk et al., 2003a). Moreover, we have shown that expression levels of nucleoside transporters and adenosine transport were

$\triangle$ Corresponding author: Katarzyna Kocbuch, Department of Molecular Medicine, Medical University of Gdańsk, Debinki 7, paw. 29, 80-211 Gdańsk, Poland; tel/fax: (48) 58349 2759; e-mail: katkocbuch@gumed.edu.pl Abbreviations: AK, adenosine kinase; ADA, adenosine deaminase; 5'-NT, 5'-nucleotidase. 
significantly altered in some tissues of diabetic rats, including lymphocytes (Sakowicz et al., 2004; 2005). We also reported that the expression level of adenosine kinase (AK) was greatly reduced in diabetic $T$ lymphocytes, suggesting that the AMP-adenosine metabolic cycle might be impaired under diabetic conditions (Pawelczyk et al., 2003b). These observations indicate that under diabetic conditions adenosine homeostasis is disturbed, which in turn may be related to impaired function of immune cells. To date, there is no data on insulin and glucose effects on adenosine-metabolizing enzymes in human lymphocytes. In this report, we present evidence indicating that glucose and insulin affect the activities of adenosine-metabolizing enzymes in human B lymphocytes, but in a different way as that observed in $\mathrm{T}$ cells.

\section{MATERIALS AND METHODS}

Reagents. Insulin, penicillin, streptomycin, glucose, adenosine, inosine, hypoxanthine, AMP, 2-deoxycoformycin, RPMI-1640 medium and leupeptin were obtained from Sigma-Aldrich Sp. z o.o. (Poznań, Poland). Pefabloc SC was from Roche Diagnostics $\mathrm{GmbH}$ (Mannheim, Germany). Fetal bovine serum (FBS) was from Gibco Invitrogen Co. (Carlsbad, CA, USA). Dynal B Cell Negative Isolation Kit, and Dynabeads Untouched Human T Cells Kit were from Invitrogen Dynal AS, (Oslo, Norway). $\left[2,8-{ }^{3} \mathrm{H}\right]$ adenosine and $\left[2,8-{ }^{3} \mathrm{H}\right] \mathrm{AMP}$ were from $\mathrm{Am}-$ ersham (Buckinghamshire, England). $\left[8^{-14} \mathrm{C}\right]$ adenine was from Moravek Biochemicals Inc. (Brea, CA, USA). Thin-layer chromatography (TLC) sheets DC Alufolien Kieselgel $60 \mathrm{~F}_{254}$ were from Merck Sp. z o.o. (Warszawa, Poland).

Cells and culture conditions. Human B and $\mathrm{T}$ lymphocytes were separated from peripheral blood using Dynabeads coated with specific monoclonal antibodies according to manufacturer's protocol. The SKW 6.4 cell line was kindly provided by Dr. Peter H. Krammer from the German Cancer Research Centre in Heidelberg (Germany). This cell line is a human IL-6-dependent, IgM-secreting B-cell line developed by transformation of B lymphocytes with Epstein-Barr virus. Cells were maintained under standard conditions $\left(5 \% \mathrm{CO}_{2} / 95 \%\right.$ air, $98 \%$ humidity, $37^{\circ} \mathrm{C}$ ) in RPMI-1640 medium, supplemented with penicillin $(100 \mathrm{U} / \mathrm{ml})$, streptomycin $(100 \mu \mathrm{g} / \mathrm{ml})$, and $10 \%$ FBS. Cells were cultured in flat-bottomed culture bottles (Sarstedt) and when necessary were split to maintain a density of about $5 \times 10^{5}$ cells $/ \mathrm{ml}$. The experiments were performed on quiescent cells cultured for $48 \mathrm{~h}$ in a medium containing 1\% FBS. Under such conditions cells do not proliferate and stay viable for at least 5 days. The impact of defined glucose and insulin concentrations (detailed in figure legends) on cellular metabolizm was assessed after $48 \mathrm{~h}$. The number of viable cells was determined by Trypan Blue dye exclusion. Only cell cultures with a $95 \%$ or greater viability were used.

Measurement of enzyme activities. Cells (about $4 \times 10^{7}$ ) were suspended in $0.5 \mathrm{ml}$ of $50 \mathrm{mM}$ Tris/ $\mathrm{HCl}$, pH 7.2, containing $0.2 \mathrm{mM}$ Pefabloc SC and $5 \mu \mathrm{M}$ leupeptin, and sonicated $(2 \times 10 \mathrm{~s})$. Resulting cell extract was centrifuged at $50000 \times \mathrm{g}$ for $45 \mathrm{~min}$, and supernatant was stored at $-20^{\circ} \mathrm{C}$ as the cytosolic fraction. The sediment from the $50000 \times g$ centrifugation was washed twice by suspension in homogenization buffer. The pellet was finally suspended in homogenization buffer containing $0.2 \%$ Triton X-100, and homogenized. The resulting homogenate was used as a membrane fraction. The activities of 5'-nucleotidase $\left(5^{\prime}-\mathrm{NT}\right)$ and adenosine deaminase (ADA) in cytosolic fraction were measured spectrophotometrically with $100 \mu \mathrm{M}$ AMP as substrate (Pawelczyk et al., 1992). The activity of adenosine kinase (AK) was assayed by the radiochemical method with $1 \mu \mathrm{M}\left[2,8-{ }^{3} \mathrm{H}\right]$ adenosine 1-2 $\mathrm{Ci} \mathrm{nmol}^{-1}$ ) as substrate (Pawelczyk et al., 1992). The activities of $5^{\prime}$-ectonucleotidase (ecto-5'-NT) and ADA in membrane fraction were assayed by radiochemical method with $100 \mu \mathrm{M}\left[2,8-{ }^{3} \mathrm{H}\right]$ AMP $(0.5-1$ $\mu \mathrm{Ci} \mathrm{nmol}^{-1}$ ). Transferring an aliquot of reaction mixture to $0.4 \mathrm{M}$ perchloric acid terminated the reaction. The obtained perchloric acid extracts were neutralized and the reaction products were separated on TLC silica gel plates. For separation of nucleotides the plate was developed in 1,4-dioxane $/ 25 \%$ ammonia/water (6:1:3.8, by vol.). Separation of purine nucleosides was performed on the plate developed in butan-1$\mathrm{ol} /$ methanol/ethyl acetate/ammonia (7:3:4:4, by vol.). The purine compounds were localized under UV, the spots were cut out and the radioactivity was counted. All enzyme assays were done at $25^{\circ} \mathrm{C}$ under conditions where the product formation was linear with time and with the amount of protein added, with no more than $20 \%$ of the substrate consumed.

Radiolabeling of cellular ATP. To evaluate the adenosine release during ATP catabolism, cells were first incubated for $1 \mathrm{~h}$ with $10 \mu \mathrm{Ci}$ [8${ }^{14} \mathrm{C}$ ]adenine $\left(45 \mathrm{mCi} \mathrm{mmol}{ }^{-1}\right)$ to label intracellular ATP. After incubation for $1 \mathrm{~h}$, the cells were washed with glucose-free RPMI-1640 medium. Examination of radiolabeled cell extracts by TLC (as described above) showed that about $75 \%$ of the cellular acidsoluble radioactivity was incorporated in ATP, ADP, and AMP (not shown). There were no significant differences in the levels of radioactivity incorporated into individual purine nucleotides irrespective of insulin and glucose concentrations.

ATP depletion. Depletion of ATP was achieved by utilizing a well-established in vitro model of metabolic stress (Pawelczyk et al., 2005; 
Podgorska et al., 2006). In brief, the cells were exposed to glucose-free RPMI-1640 medium containing $10 \mathrm{mM}$ 2-deoxyglucose (an inhibitor of glycolysis) and incubated at $37^{\circ} \mathrm{C}$ in a humidified atmosphere containing $5 \% \mathrm{CO}_{2}$. At predetermined time points (indicated in the figures), an aliquot $(100 \mu \mathrm{l})$ of cell suspension was withdrawn for determination of purine compounds. Cell viability was quantified over time using Trypan Blue. There was no loss of cell viability over the first hour of incubation.

Measurement of ATP catabolism and adenosine release. ATP was measured using a luciferasebased bioluminescent ATP assay kit (Sigma-Aldrich) as described previously (Podgorska et al., 2006). The ATP levels were expressed in nmol (mg cellular protein $)^{-1}$. The levels of purine nucleosides and nucleotides in culture media were determined as follows. An aliquot $(50 \mu \mathrm{l})$ of cell suspension was withdrawn and placed on top of silicone fluid and immediately centrifuged (Sakowicz et al., 2005). The resulting aqueous layer (top) was extracted with $0.4 \mathrm{M}$ perchloric acid, neutralize and purine compound were separated by TLC as described above.

Statistical analysis. Statistical analysis was performed with ANOVA or Dunnett's test for comparison with control group. Paired Student's $t$-test was performed when two groups were analyzed. $P$ values below 0.05 were considered as significant.

\section{RESULTS}

\section{Activities of adenosine-metabolizing enzymes as a function of glucose and insulin concentration}

The activity of adenosine deaminase (ADA) in the cytosolic fraction of SKW 6.4 cells was very low. In cells cultured with $25 \mathrm{mM}$ glucose small decrease of cytosolic ADA activity could be observed comparing to cells cultured with $5 \mathrm{mM}$ glucose, but it was not statistically significant (Fig. 1A). Rising the glucose level from $5 \mathrm{mM}$ to $25 \mathrm{mM}$ resulted in an about $35 \%$ decrease of ADA activity associated with plasma membranes regardless of insulin concentration (Fig. 1B). Our measurements showed that the activities of $5^{\prime}$-nucleotidase (5'-NT) and ecto-5'-NT in SKW 6.4 cells depended on insulin concentration, but not on that of glucose (Fig. 2). Cells cultured with $10^{-8} \mathrm{M}$ insulin displayed an about $60 \%$ lower activity of cytosolic 5'-NT comparing to cells maintained at $10^{-11} \mathrm{M}$ insulin, irrespective of glucose concentration (Fig. 2A). The activity of ecto-5'-NT was decreased by about $70 \%$ in cells cultured with $5 \mathrm{mM}$ glucose and $10^{-8} \mathrm{M}$ insulin comparing to cells grown at $5 \mathrm{mM}$ glucose and $10^{-11} \mathrm{M}$ insulin (Fig. 2B). The effect of insulin concentration on the activity of ecto$5^{\prime}$-NT was significantly weaker in cells cultured at
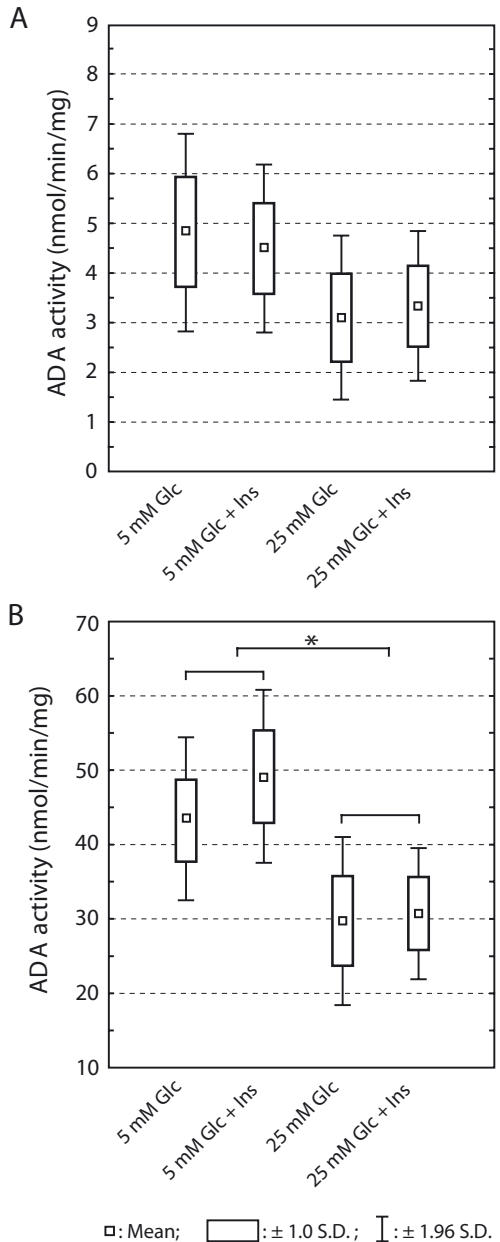

Figure 1. Activity of adenosine deaminase (ADA) in human B lymphocytes SKW 6.4 cultured at different glucose and insulin concentrations.

Cells were cultured for 2 days in medium containing glucose at concentrations as indicated. Ins., refers to insulin concentration of $10^{-8} \mathrm{M}$. The insulin concentration in conditions described as (5 mM Glc) or (25 mM Glc) was $\leq 10^{-11}$ M. On third day cells were harvested and ADA activity in cytosolic (A) and membrane (B) fractions was determined as described in Materials and Methods. Data represent mean from at least four independent experiments. ${ }^{*} P<0.05$.

high glucose. An increase of insulin concentration from $10^{-11} \mathrm{M}$ to $10^{-8} \mathrm{M}$ resulted in a decrease of ecto$5^{\prime}$-NT activity by about $45 \%$ in cells cultured with $25 \mathrm{mM}$ glucose. Neither insulin nor glucose had an effect on adenosine kinase (AK) activity in the human SKW 6.4 cells (Table 1). Our previous work has documented that insulin up-regulates AK expression in rat T lymphocytes (Pawelczyk et al., 2003b; 2005; Sakowicz-Burkiewicz et al., 2006). The lack of insulin effect on AK activity in SKW 6.4 cells could be a specific feature of Epstein-Barr-transformed cells or could result from differences in the regulatory mechanisms functioning in $\mathrm{B}$ and $\mathrm{T}$ lymphocytes. A possible involvement of species difference should also be considered. The effect of insulin on AK ex- 

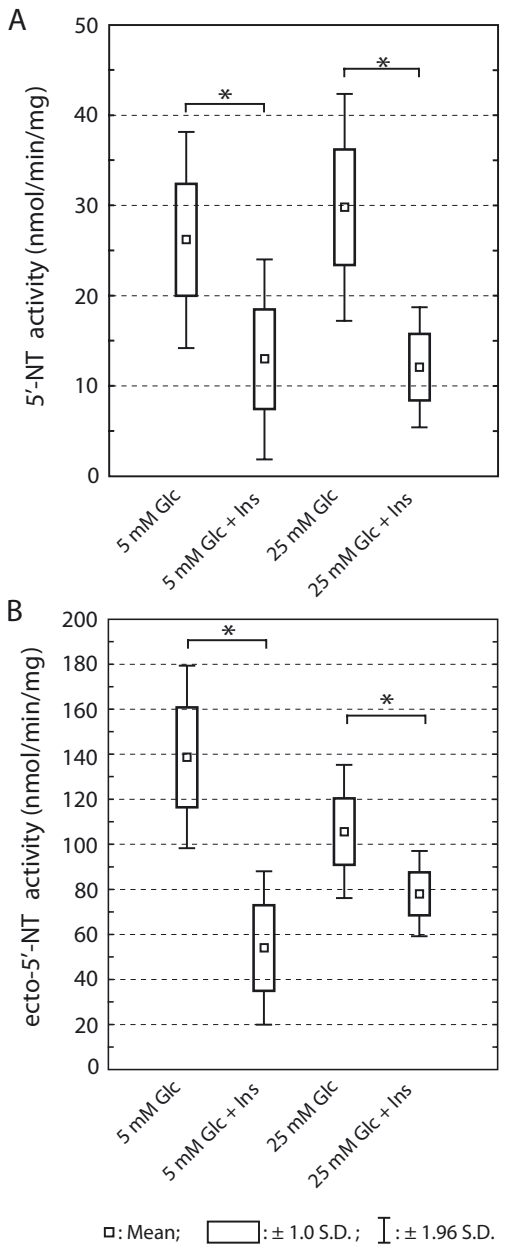

Figure 2. Activity of $5^{\prime}$-nucleotidase $\left(5^{\prime}-\mathrm{NT}\right)$ in human $B$ lymphocytes SKW 6.4 cultured at different glucose and insulin concentrations.

Cells were cultured for 2 days in medium containing glucose at concentrations as indicated. Ins., refers to insulin concentration of $10^{-8} \mathrm{M}$. Insulin concentration in conditions described as (5 mM Glc) or (25 mM Glc) was $\leq 10^{-11}$ M. On third day cells were harvested and 5'-NT activity in cytosolic (A) and ecto-5'-NT activity in membrane (B) fractions was determined as described in Materials and Methods. Data represent mean from at least five independent experiments. ${ }^{*} P<0.05$.

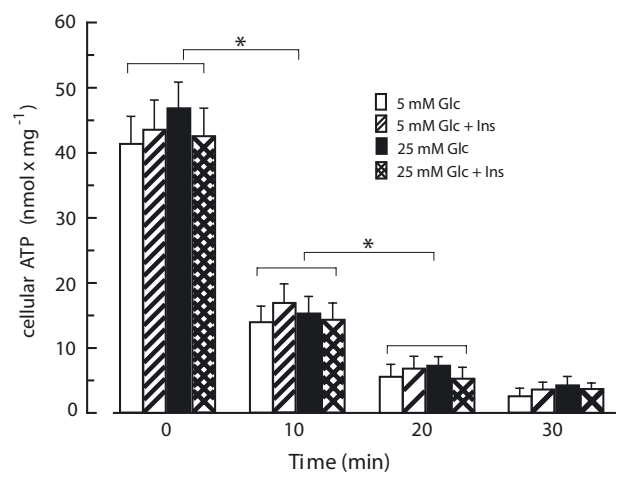

Figure 3. Level of ATP in SKW 6.4 cells exposed to glycolytic inhibitor 2-deoxyglucose.

Cells were cultured for 2 days in medium containing glucose and insulin at concentrations as indicated. Ins., refers to insulin concentration of $10^{-8} \mathrm{M}$. Insulin concentration in conditions described as (5 mM Glc) or $(25 \mathrm{mM}$ Glc) was $\leq 10^{-11} \mathrm{M}$. On third day cells were labeled with $\left[8-{ }^{14} \mathrm{C}\right]$ adenine, washed, suspended in glucose-free RPMI medium and ATP depletion was induced by addition of 2-deoxyglucose $(10 \mathrm{mM})$. Data represent mean \pm S.D. from four independent experiments. ${ }^{*} P<0.05$.

pression and activity has not been investigated in rat B lymphocytes or human $\mathrm{T}$ and $\mathrm{B}$ lymphocytes to date. Our present experiments demonstrated that the AK activity was not affected in human peripheral B cells or in rat B lymphocytes, whereas both in human and rat $\mathrm{T}$ lymphocytes insulin stimulated in a dose-dependent manner the AK activity (Table 1).

Effect of glucose and insulin on extracellular level of purine nucleosides under altered cellular level of ATP

Induction of ATP catabolism by 2-deoxyglucose in the absence of glucose resulted in a rapid and profound decrease of intracellular ATP level to about $7 \%$ of control within $30 \mathrm{~min}$. There were no differences in the rate of ATP decline irrespective of glucose and insulin concentrations in the cell culture medium (Fig. 3). The intracellular level of purine nucleosides and bases increased transiently during

Table 1. Adenosine kinase (AK) activity in human and rat lymphocytes incubated in the presence of various glucose and insulin concentrations.

Lymphocytes were cultured for 2 days in medium containing glucose and insulin at concentrations as indicated. On third day cells were harvested and AK activity was determined in cytosolic fractions as described in Materials and Methods. Data represent mean \pm S.D. from three independent experiments. ${ }^{*} P<0.05$ versus $10^{-8} \mathrm{M}$ insulin. ${ }^{\#}$ data from Pawelczyk et al., 2005.

\begin{tabular}{lcccc}
\hline \multicolumn{4}{l}{$\begin{array}{l}\text { Adenosine kinase activity } \\
\text { (nmol/min per mg) }\end{array}$} & \\
\cline { 2 - 5 } Cell type & $5 \mathrm{mM}$ glucose & $5 \mathrm{mM}$ glucose & $25 \mathrm{mM}$ glucose & $25 \mathrm{mM}$ glucose \\
& insulin $\left(10^{-8} \mathrm{M}\right)$ & insulin $\left(\leq 10^{-11} \mathrm{M}\right)$ & insulin $\left(10^{-8} \mathrm{M}\right)$ & insulin $\left(\leq 10^{-11} \mathrm{M}\right)$ \\
\hline Rat B lymphocytes & $14.10 \pm 0.95$ & $12.14 \pm 0.71$ & $11.32 \pm 0.85$ & $13.49 \pm 0.79$ \\
Rat T lymphocytes & $27.91 \pm 1.90$ & $7.61 \pm 0.52^{*}$ & $29.93 \pm 1.18$ & $7.32 \pm 0.49^{*}$ \\
Human peripheral B lymphocytes & $8.42 \pm 0.77$ & $7.98 \pm 0.63$ & $6.88 \pm 0.54$ & $9.28 \pm 0.81$ \\
Human peripheral T lymphocytes & $15.91 \pm 1.10$ & $4.25 \pm 0.35^{*}$ & $16.23 \pm 1.33$ & $5.01 \pm 0.49^{*}$ \\
SKW 6.4 lymphocytes & $15 \pm 4.27$ & $16.92 \pm 3.05$ & $13.57 \pm 2.86$ & $14.28 \pm 1.43$ \\
\hline
\end{tabular}




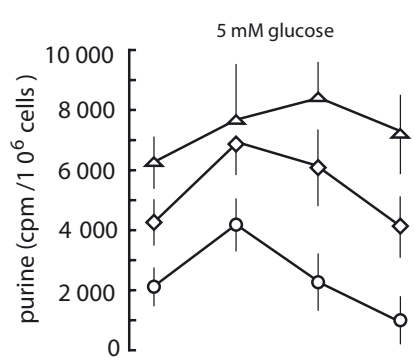

$5 \mathrm{mM}$ glucose $+10 \mathrm{nM}$ insulin
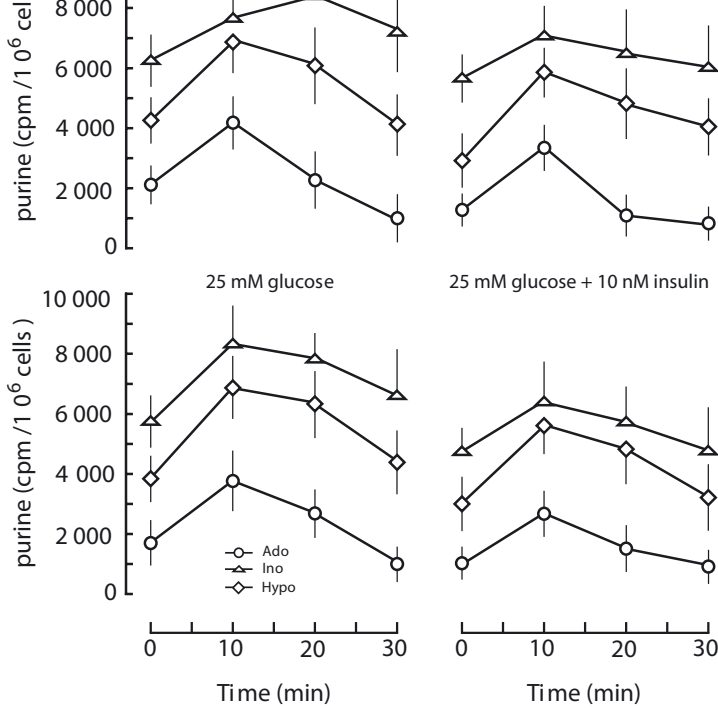

$25 \mathrm{mM}$ glucose $+10 \mathrm{nM}$ insulin

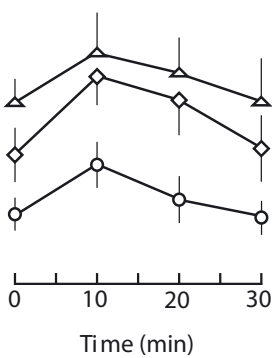

Figure 4. Level of adenosine, inosine and hypoxanthine in SKW 6.4 cells subjected to 2-deoxyglucose-induced ATP degradation.

Cells were cultured for 2 days in medium containing glucose and insulin at concentrations as indicated. Insulin concentration in conditions described as (5 $\mathrm{mM} \mathrm{Glc)}$ or (25 mM Glc) was $\leq 10^{-11} \mathrm{M}$. On third day cells were labeled with $\left[8-{ }^{14} \mathrm{C}\right]$ adenine, washed, suspended in glucosefree RPMI medium and ATP depletion was induced by addition of 2-deoxyglucose $(10 \mathrm{mM})$. At indicated times, $200 \mu$ of cell culture $\left(10^{6}\right.$ cells) was withdrawn, cells were separated by centrifugation, and the level of radioactivity in adenosine, inosine, and hypoxanthine was analyzed by TLC as described in Material and Methods. Data represent mean \pm S.D. from three independent experiments. ${ }^{*} P<0.05$.

the first $10 \mathrm{~min}$ of incubation with 2-deoxyglucose. There were no differences in the rate of changes in the intracellular levels of adenosine, inosine and hypoxanthine between cells cultured at different insulin and glucose concentrations (Fig. 4). The decrease in cellular ATP level was accompanied by increased adenosine, inosine and hypoxanthine concentrations in the medium. The extracellular concentration of adenosine varied depending on glucose concentration. The level of adenosine was significantly higher in the medium of cells cultured with low glucose $(5 \mathrm{mM})$ than in the medium of cells maintained at $25 \mathrm{mM}$ glucose (Fig. 5). A similar association between glucose concentration in the cell culture media and inosine level was observed. Moreover, the rate of the increase of adenosine and inosine levels was significantly higher in cell culture media containing low glucose. Insulin had no effect on adenosine and inosine level in media of SKW 6.4 cells cultured with 2-deoxyglucose. However, the hypoxanthine level did depend on insulin but not on glucose level in the medium. Cells cultured in the pres- ence of $10^{-8} \mathrm{M}$ insulin released more hypoxanthine comparing to cells grown with $10^{-11} \mathrm{M}$ insulin, irrespective of glucose concentration (Fig. 5). Moreover, the rate of hypoxanthine release was higher for cells cultured with $10^{-8} \mathrm{M}$ insulin than in those grown with $10^{-11} \mathrm{M}$ insulin. In order to evaluate the impact of ADA activity on nucleoside levels the cells, prior to induction of ATP catabolism with 2-deoxyglucose were preincubated with $20 \mu \mathrm{M} 2$ '-deoxycoformycin. Inhibition of ADA activity resulted in an increase of adenosine and a decrease of inosine and hypoxanthine levels in the medium. However, the changes in adenosine and inosine levels were not statistically significant except for cells cultured with $5 \mathrm{mM}$ glucose and $10^{-8} \mathrm{M}$ insulin (Table 2). The level of hypoxanthine in the medium decreased significantly for cells cultured in the presence of $10^{-8} \mathrm{M}$ insulin, irrespective of glucose concentration.

\section{DISCUSSION}

The data presented here indicate that glucose and insulin differentially affect the activity of adenosine deaminase and 5'-nucleotidase in SKW 6.4 lymphocytes but has no effect on adenosine kinase activity. Previously we reported that rat $\mathrm{T}$ lymphocytes cultured in the low insulin $\left(\leq 10^{-11} \mathrm{M}\right.$, presented in FBS) displayed a about $70 \%$ lower AK activity than in those grown in medium supplemented with insulin to reach the concentration of $10^{-8} \mathrm{M}$ insulin (Pawelczyk et al., 2005). Similar insulin effect on AK activity was observed in $\mathrm{T}$ lymphocytes isolated from human blood. No such relationship between insulin concentration and AK activity was observed in rat or in human B cells. These observations indicate that the effect of insulin on AK activity is a celltype-specific and is not related to species.

The levels of nucleotides in the cell under metabolic stress depend not only on their de novo synthesis but also on salvage reactions, which consume less energy. The phosphorylation of adenosine to AMP catalyzed by AK is one such reaction. Our results presented in this report indicate that the 2deoxyglucose-induced fall in ATP level proceeded at a similar rate in B cells regardless of glucose and insulin concentration in the culture media. This is different than in rat $\mathrm{T}$ lymphocytes exposed to 2-deoxyglucose, which under high glucose concentration displayed a much faster decline in ATP level comparing to cells cultured with $5 \mathrm{mM}$ glucose (Pawelczyk et al., 2005). We observed that under metabolic stress conditions B cells cultured in high concentration of glucose released less adenosine comparing to cells cultured at low glucose, regardless of insulin concentration. Different changes in adenosine level were observed in rat $\mathrm{T}$ cells, which during acceler- 

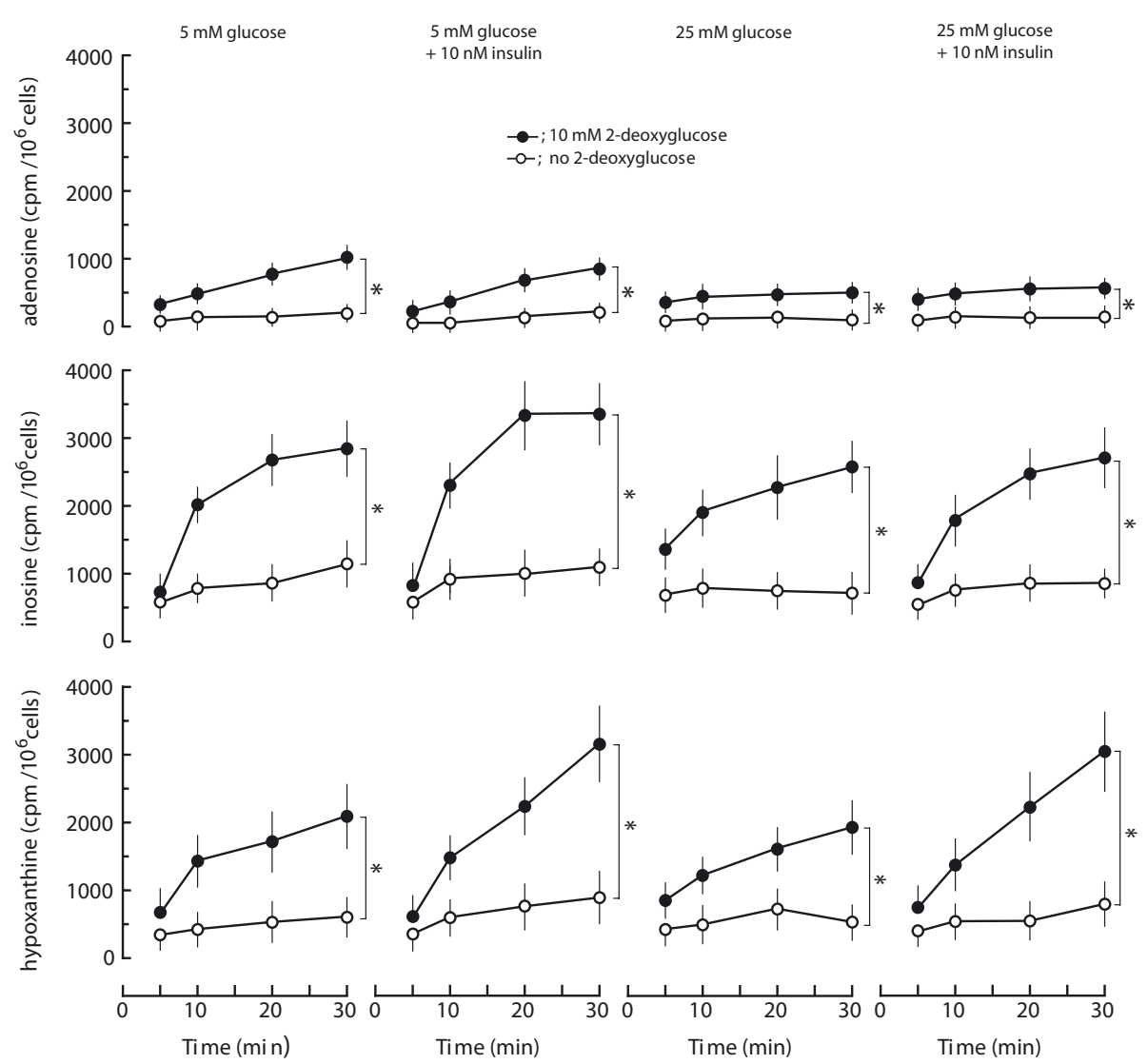

Figure 5. Outflow of purine nucleosides and bases from SKW 6.4 cells during 2-deoxyglucose-induced ATP degradation.

Cells were cultured for 2 days in medium containing glucose and insulin at concentrations as indicated. Ins., refers to insulin concentration of $10^{-8} \mathrm{M}$. Insulin concentration in conditions described as (5 mM Glc) or ( $25 \mathrm{mM}$ Glc) was $\leq 10^{-11} \mathrm{M}$. On third day cells were labeled with $\left[8-{ }^{14} \mathrm{C}\right]$ adenine, washed, suspended in glucose-free RPMI medium and ATP depletion was induced by addition of 2-deoxyglucose $(10 \mathrm{mM})$. To control cells equal volume of water was added. At indicated times, $200 \mu \mathrm{l}$ of culture medium was withdrawn and the level of radioactivity in adenosine, inosine, and hypoxanthine was analyzed by TLC as described in Material and Methods. Data represent mean \pm S.D. from four independent experiments. ${ }^{*} P<0.05$.

ated ATP catabolism released more adenosine when cultured at high glucose. Our present results indicate that the activity of cytosolic and membrane-associated ADA increased in B cells cultured at high glucose and was not affected by insulin. The small contribution of ADA activity to the adenosine and inosine levels in media of cultured B cells was confirmed by experiments with the use of 2-deoxycoformycin. Inhibition of ADA activity resulted only in small changes in adenosine and inosine levels. On

Table 2. Effect of 2-deoxycoformycin on adenosine, inosine and hypoxanthine levels in culture medium of SKW 6.4 cells exposed to 2-deoxyglucose.

Lymphocytes were cultured for 2 days in medium containing glucose and insulin at concentrations as indicated. On third day cells were labeled with $\left[8-{ }^{14} \mathrm{C}\right]$ adenine, washed, suspended in glucose-free RPMI medium containing $50 \mu \mathrm{M} 2$-deoxycoformycin $(+\mathrm{DCF})$ or not $(-\mathrm{DCF})$ and after $10 \mathrm{~min}$ ATP depletion was induced by addition of 2-deoxyglucose (10 mM). Thirty minutes after 2-deoxyglucose addition, $200 \mu \mathrm{l}$ of culture medium was withdrawn and the level of radioactivity in adenosine, inosine, and hypoxanthine was analyzed by TLC as described in "Material and Methods". Data represent mean \pm S.D. from four independent experiments. ${ }^{*} P<0.05$ versus (-DCF).

\begin{tabular}{|c|c|c|c|c|c|c|c|c|}
\hline \multirow{3}{*}{$\begin{array}{l}\text { Nucleoside/ } \\
\text { nucleobase }\end{array}$} & \multicolumn{2}{|c|}{$\begin{array}{l}5 \mathrm{mM} \text { glucose } \\
\text { insulin }\left(\leq 10^{-11} \mathrm{M}\right)\end{array}$} & \multicolumn{2}{|c|}{$\begin{array}{l}5 \mathrm{mM} \text { glucose } \\
\text { insulin }\left(10^{-8} \mathrm{M}\right)\end{array}$} & \multicolumn{2}{|c|}{$\begin{array}{l}25 \mathrm{mM} \text { glucose } \\
\text { insulin }\left(\leq 10^{-11} \mathrm{M}\right)\end{array}$} & \multicolumn{2}{|c|}{$\begin{array}{l}25 \mathrm{mM} \text { glucose } \\
\text { insulin }\left(10^{-8} \mathrm{M}\right)\end{array}$} \\
\hline & $+\mathrm{DCF}$ & $-\mathrm{DCF}$ & $+\mathrm{DCF}$ & $-\mathrm{DCF}$ & + DCF & $-\mathrm{DCF}$ & $+\mathrm{DCF}$ & $-\mathrm{DCF}$ \\
\hline & \multicolumn{8}{|c|}{$\mathrm{cpm} / 10^{6}$ cells } \\
\hline Adenosine & $1201 \pm 129$ & $1058 \pm 143$ & $1192 \pm 139^{*}$ & $823 \pm 96$ & $778 \pm 119$ & $598 \pm 141$ & $6 \pm 129$ & $821 \pm 163$ \\
\hline Inosine & $2405 \pm 429$ & $2928 \pm 413$ & $2521 \pm 437^{*}$ & $3395 \pm 461$ & $2010 \pm 321$ & $2695 \pm 387$ & $2752 \pm 474$ & $2250 \pm 405$ \\
\hline Hypoxanthine & $1316 \pm 496$ & $2101 \pm 478$ & $1720 \pm 417^{*}$ & $3195 \pm 587$ & $1210 \pm 279$ & $1850 \pm 398$ & $1331 \pm 383^{*}$ & $3020 \pm 584$ \\
\hline
\end{tabular}


the other hand, the activity of the adenosine-producing enzyme 5'-NT decreased in the cytoplasm and in plasma membranes of cells cultured in the presence of $10^{-8} \mathrm{M}$ insulin. These changes in the activity of $5^{\prime}$-NT did not correlate with adenosine levels in cell culture media. We observed that adenosine level was significantly higher in media of cells cultured at low glucose comparing to cells cultured at high glucose regardless of insulin concentration. These observations might indicate that the extracellular level of adenosine in B cells during accelerated ATP catabolism depends mainly on its transport, and is not related to activities of adenosine metabolizing enzymes.

Studies performed on B cell lines and isolated rat spleen B lymphocytes indicate that these cells express both the concentrative (CNT2), and the equilibrative (ENT1, ENT2) nucleoside transporters (Pastor-Anglada et al., 2001; Sakowicz et al., 2005). Our previous work documented that in rat B and $\mathrm{T}$ cells the expression level of ENT1 is significantly suppressed by high glucose, whereas expression of ENT2 and CNT2 transporters is regulated by insulin and is not affected by glucose level (Sakowicz et al., 2004; 2005). Therefore, the relatively low level of adenosine and inosine in media of cells cultured in the presence of $25 \mathrm{mM}$ glucose could be the result of decreased equilibrative transport facilitated by ENT1. This transporter's activity contributes about $80 \%$ of overall adenosine transport in rat $\mathrm{B}$ and $\mathrm{T}$ cells. The hypoxanthine level was significantly higher in media of cells cultured in the presence of $10^{-8} \mathrm{M}$ insulin regardless of glucose concentration. The only nucleoside carrier capable of transporting hypoxanthine is ENT2 (Baldwin et al., 1999; Podgorska et al., 2005), whose expression level is very low in B cells cultured in the low insulin. Previously we have shown that an increase in insulin concentration results in increased ENT2 expression (Sakowicz et al., 2005).

Concluding, the results of our study demonstrate that glucose and insulin differentially affect the adenosine-metabolizing enzymes activities in human B cell line SKW 6.4, but changes in those activities do not correlate with adenosine level in the cell media during accelerated ATP catabolism, implying a rate-limiting role of nucleoside carriers in adenosine outflow from the cell. Moreover, the presented data highlight significant differences in adenosine metabolism between human $\mathrm{T}$ and $\mathrm{B}$ lymphocytes subjected to various insulin and glucose concentrations.

\section{Acknowledgements}

K.K. is a recipient of stipend from the Polpharma Foundation for Development of Polish Pharmacy and Medicine.
This work was supported by the Ministry of Science and Higher Education grant No. 2 P05A 081 29 to T.P. and grant No. W-159 to K.K.

\section{REFERENCES}

Baldwin SA, Mackey JR, Cass CE, Young JD (1999) Nucleoside transporters: molecular biology and implications for therapeutic development. Mol Med Today 5: 216-224.

Fredholm BB, Irenius E, Kull B, Schulte G (2001) Comparison of the potency of adenosine as an agonist at human adenosine receptors expressed in Chinese hamster ovary cells. Biochem Pharmacol 61: 443-448.

Gessi S, Varani K, Merighi S, Fogli E, Sacchetto V, Benini A, Leung E, MacLennan S, Borea PA (2007) Adenosine and lymphocyte regulation. Purinergic Signal 3: 109116.

Hasko G, Crostein B (2004) Adenosine: an endogenous regulator of innate immunity. Trends Immunol 25: 33-39.

Hasko G, Linden J, Cronstein B, Pacher P (2008) Adenosine receptors: therapeutic aspects for inflammatory and immune diseases. Nat Rev Drug Discov 7: 759-770.

Hershfield MS (2005) New insights into adenosine-receptor-mediated immunosuppression and the role of adenosine in causing the immunodeficiency associated with adenosine deaminase deficiency. Eur J Immunol 35: 25-30.

Martin C, Leone M, Viviand X, Ayem ML, Guieu R (2000) High adenosine plasma concentration as a prognostic index for outcome in patients with septic shock. Crit Care Med 28: 3198-3202.

Pastor-Anglada M, Casado FJ, Valdés R, Mato J, GarciaManteiga J, Molina M (2001) Complex regulation of nucleoside transporter expression in epithelial and immune system cells. Mol Membr Biol 18: 81-85.

Pawelczyk T, Bizon D, Angielski S (1992) The distribution of enzymes involved in purine metabolism in rat kidney. Biochim Biophys Acta 1116: 309-314.

Pawelczyk T, Podgorska M, Sakowicz M (2003a) The effect of insulin on expression level of nucleoside transporters in diabetic rats. Mol Pharmacol 63: 81-88.

Pawelczyk T, Sakowicz M, Podgorska M, SzczepanskaKonkel M (2003b) Insulin induced expression of adenosine kinase gene in rat lymphocytes by signaling through the mitogen activated protein kinase pathway. Exp Cell Res 286: 152-163.

Pawelczyk T, Sakowicz-Burkiewicz M, Kocbuch K, Szutowicz A (2005) Differential effect of insulin and elevated glucose level on adenosine handling in rat $\mathrm{T}$ lymphocytes. J Cell Biochem 96: 1296-1310.

Podgorska M, Kocbuch K, Pawelczyk T (2005) Recent advances in studies on biochemical and structural properties of equilibrative and concentrative nucleoside transporters. Acta Biochim Polon 52: 749-758.

Podgorska M, Kocbuch K, Grden M, Szutowicz A, Pawelczyk T (2006) Reduced ability to release adenosine by diabetic rat cardiac fibroblasts due to altered expression of nucleoside transporters. J Physiol 576: 179-189.

Sakowicz M, Szutowicz A, Pawelczyk T (2004) Insulin and glucose induced changes in expression level of nucleoside transporters and adenosine transport in rat $\mathrm{T}$ lymphocytes. Biochem Pharmacol 68: 1309-1320.

Sakowicz M, Szutowicz A, Pawelczyk T (2005) Differential effect of insulin and elevated glucose level on adenosine transport in rat B lymphocytes. Int Immunol 17: 145-154. 
Sakowicz-Burkiewicz M, Kocbuch K, Grden M, Szutowicz A, Pawelczyk T (2006) Diabetes-induced decrease of adenosine kinase expression impairs the proliferation potential of diabetic rat $\mathrm{T}$ lymphocytes. Immunology 118: $402-412$.
Sperlágh B, Dóda M, Baranyi M, Haskó G (2000) Ischemiclike condition release norepinephrine and purines from different sources in suppressed rat spleen strips. J Neuroimmunol 111: 45-54. 